\title{
COMPARATIVE GEOMORPHOLOGICAL OBSERVATIONS IN TWO GROUPS OF ALLUVIAL FANS OF SPERCHIOS AND EUROTAS REGIONS, GREECE
}

\author{
Kontou A. ${ }^{1}$, Gaki-Papanastasiou K. ${ }^{1}$, and Maroukian H. ${ }^{1}$ \\ ${ }^{I}$ National and Kapodistrian University of Athens, Faculty of Geology and Geoenvironment, \\ Department of Geography-Climatology, gaki@geol.uoa.gr
}

\begin{abstract}
In the present study two groups of alluvial fans from two different regions in Greece were comparetively studied, the first in the region of Sperchios river and the second in the region of Eurotas river. Distinct morphometric characteristics of the drainage basins of the tributaries Tserlias, Xerias, Gorgopotamos, Kerasias, Retsas and Kakaris, as well as their fans were measured and compared. Furthermore, the longitudinal stream profiles were mapped, pebble measurements were made and contour crenulations of the fans were studied. In gravelometry, it was found that the mean size $M$ of the pebbles decreases from the apex to the apron of the fan. The crenulation analysis showed that the fans of the streams of Eurotas region have undergone greater erosion than those of Sperchios region. Remarkable differences exist between the fans of the two regions. These results lead to the conclusion that recent tectonism, the prevailing lithology and climate are responsible for the formation and evolution of the fans and also influence their shape, area and all the other morphometric characteristics.
\end{abstract}

Key words: drainage networks, crenulations, gravelometry.

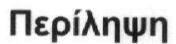

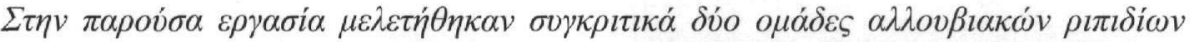

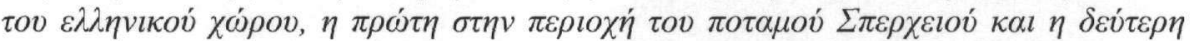

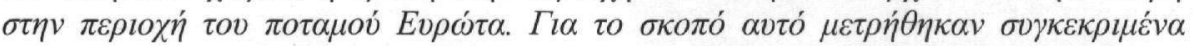

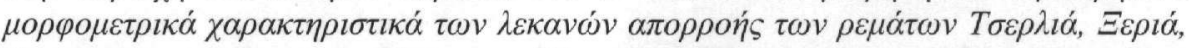

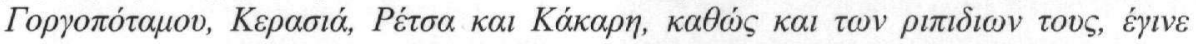

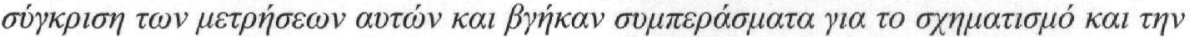

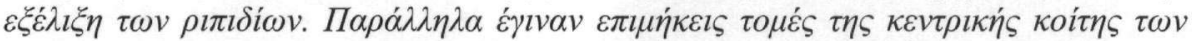

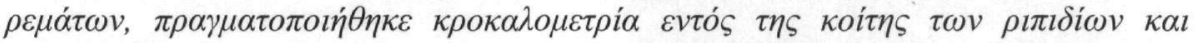

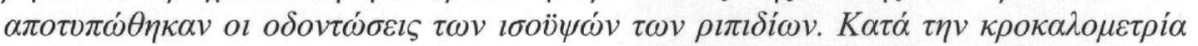

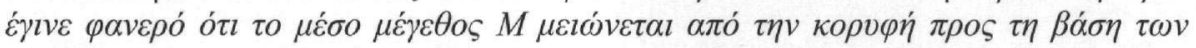

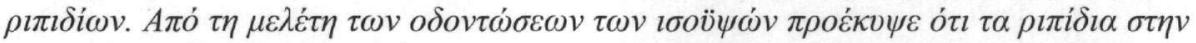

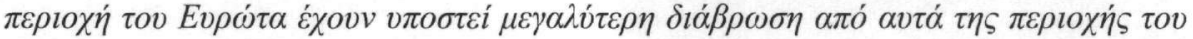

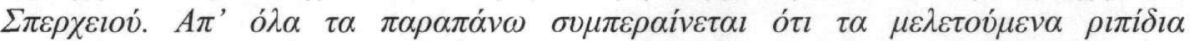

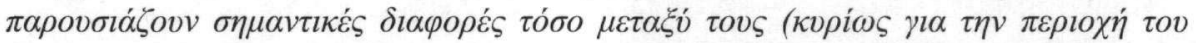

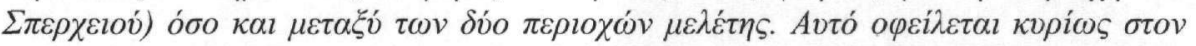

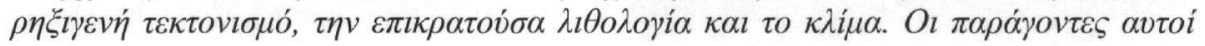




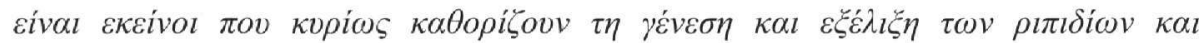

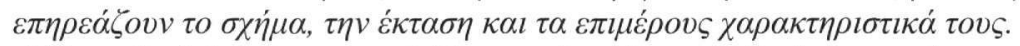

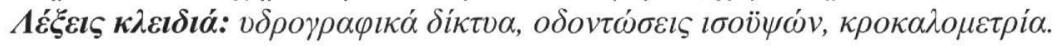

\section{Introduction}

\subsection{Geographical location - Aim of the study}

Alluvial fans are depositional landforms composed of fluvial-torrential deposits. They are created when overburdened rivers come out from a mountainous massif in a region of gentler slopes and deposit the sediments they carry in an arch - shaped form. An abrupt reduction in stream power commonly occurs at mountain-front locations (Bull 1977). Their existence is connected mainly with fault zones, while their shape and development is determined to a large extent by lithology and climate. Fan morphology also depends on other factors, such as geographic environment, vegetative cover of the drainage basin, slope of the stream, basin of deposition and human activity. Processes on fans deliver sediments principally by debris flows or fluvial sediment transport. Material is transported to fans by debris flows or water flows which follow the main channel. (Hooke 1965), (Volker et al. 2006). Many studies also emphasize on relations between sedimentary processes and morphology and on fan dynamics (Harvey 1997, 2002). Debris flow fans are steeper than fluvial fans.

In the present study two groups of alluvial fans from two different regions of Greece were comparatively studied (Fig. 1). The first is found south of the Sperchios river bed and includes the drainage basins and fans of the tributaries Tserlias, Xerias and Gorgopotamos issuing from mount Iti. The second region is found west of Eurotas river bed and includes the drainage basins and fans of the tributaries Kerasias, Retsas and Kakaris, which issue from east Taygetos mountain. Sperchios issues from Tymfristos mountain and after a $65 \mathrm{~km}$ flow, from west to east, empties in Maliakos Gulf. Eurotas issues from NE Taygetos mountain, flows from north to south reaching the Laconic Gulf after a $60 \mathrm{~km}$ journey.

The aim of the present study is the measurement and calculation of distinct parameters that concern the shape of the fans, the examination of their development in relation with the climate and the geological conditions of their regions and the comparison between fans of the same region as well as between the two studied regions. For this purpose airphotos were used, as well as topographic maps of H.A.G.S., geological maps of I.G.M.E both at scales 1:50.000, and topographic diagrams at scale 1:5.000. Digitalisation and treatment of data was done using MapInfo software.

\subsection{Geology - Tectonics}

The tectonic/stratigraphic zones of Pindos, Parnassos-Giona and Ypopelagoniki (mainly flysch and in smaller percentage limestones) participate in the geological structure of the Sperchios region, while the zones of Mani (mainly marbles) and Arna (phyllites), participate in the geological structure of Eurotas region. There also exist Neogene and Quaternary deposits (Figs 2, 3).

The main channel of Sperchios river flows in an asymmetrical tectonic graben, that is delimited to the south by the fault of Sperchiada having a W-E direction and a slope to the north, and constitutes the western extension of the long active fault zone of Kamena Bourla - Thermopyles. This fault is responsible for the asymmetry in the development of drainage networks at both sides of its watercourse, the southern part of which has uplifted (Eliet et al. 1995). The fans have developed mainly in the western part of Sperchios basin, while in the east they end in Maliakos Gulf and the N. Eubean Gulf. The orientation of the studied tributaries is usually perpendicular to the faults implying the recent tectonic control of the region. 


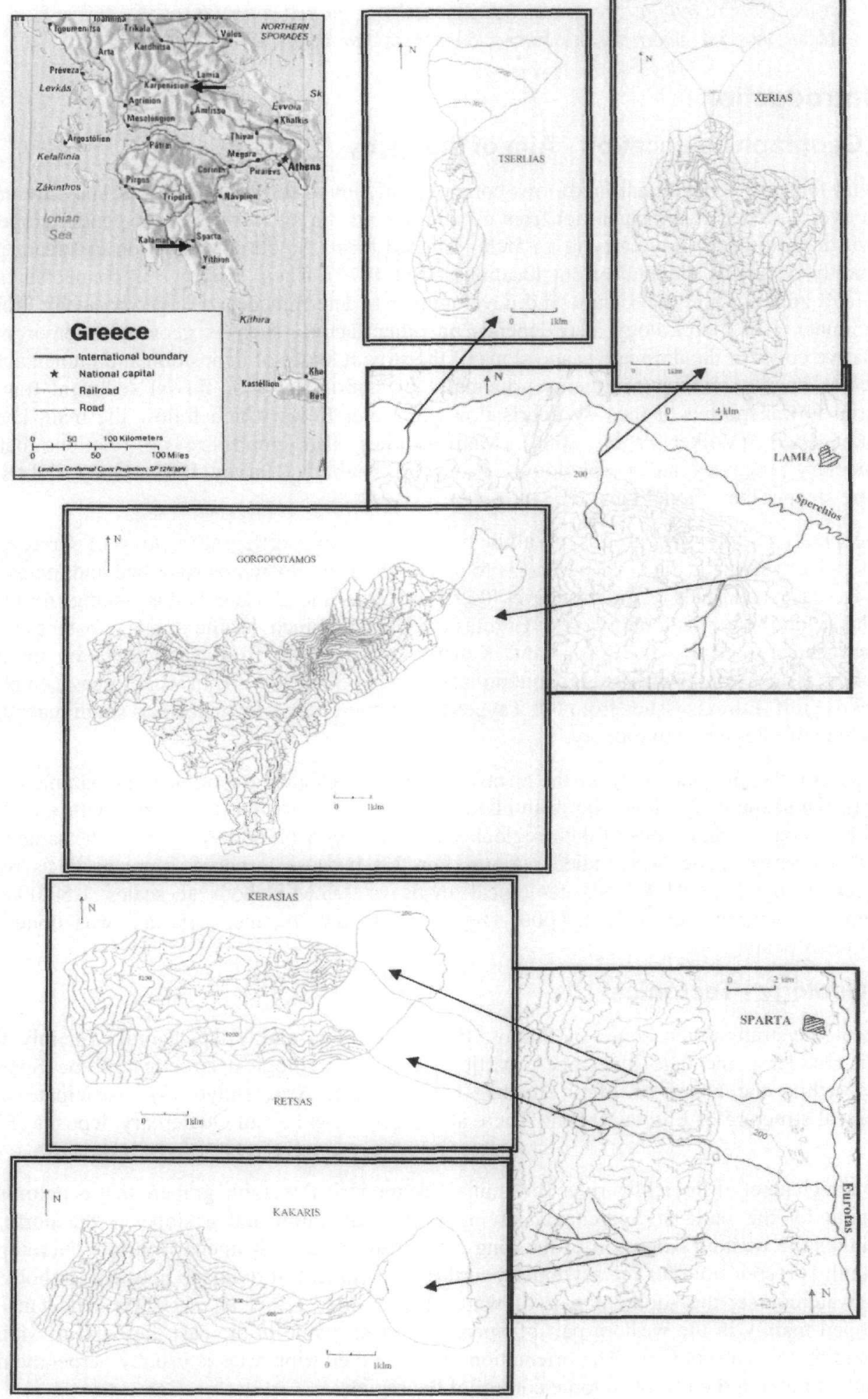

Figure 1 - Topographic maps of Sperchios and Eurotas regions (contour interval $100 \mathrm{~m}$ ) 


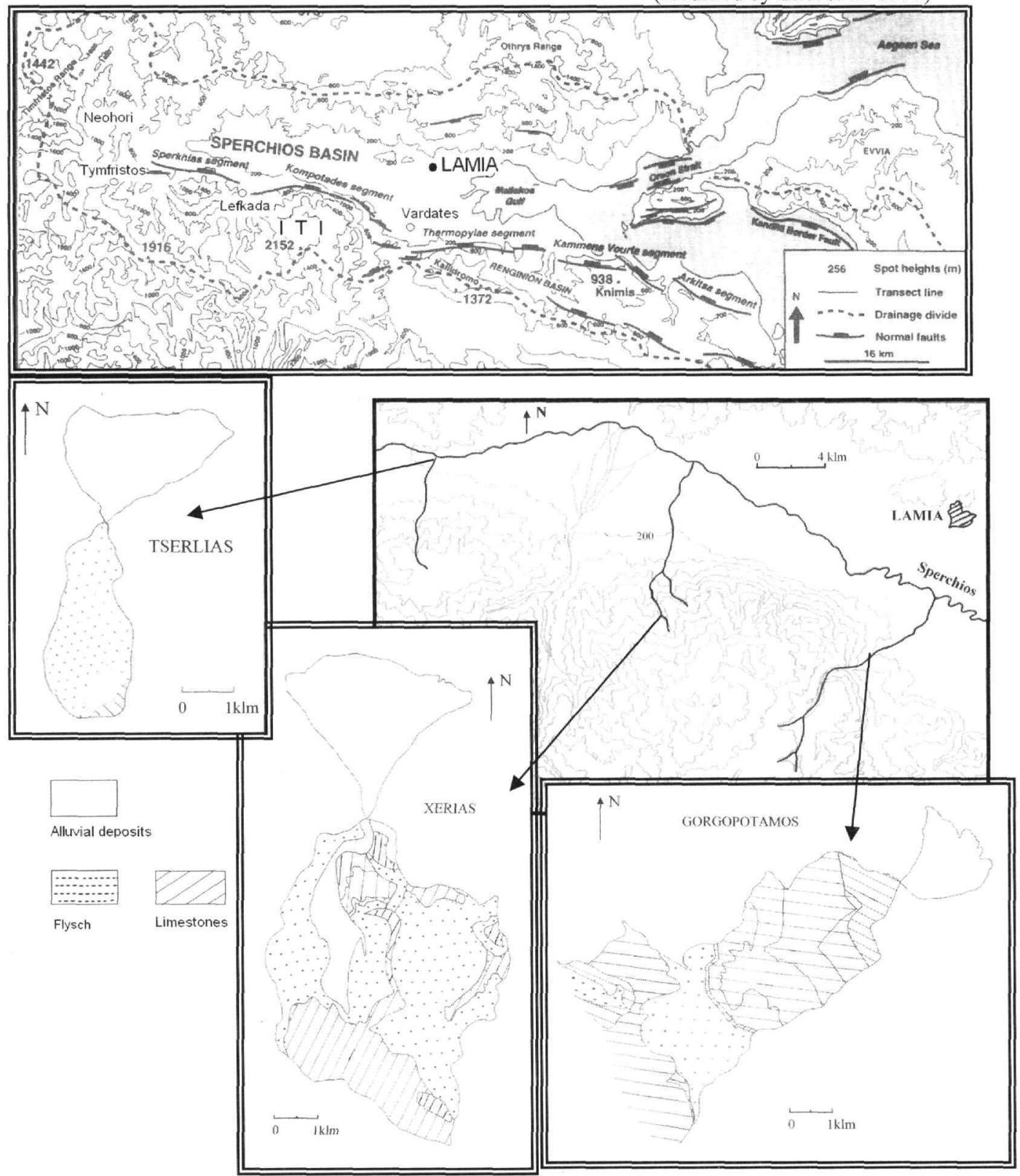

Figure 2 - Schematic geological maps of Sperchios tributaries

Eurotas basin is delimited to the west by the mountainous massif of Taygetos, whose eastern front is delineated by an active fault composed of several distinguishable segments, the southern one with a NNW-SSE orientation and a total length of $20 \mathrm{~km}$, being the Sparta fault. As a result, several knick-points and deep parallel gorges are located at the exit of Eurotas' tributaries from the mountainous massif, crossing the major fault. There is also a secondary system of conjugate faults, having an ENE-WSW direction, which has affected the flow direction of several tributaries of Eurotas river. At least two fan generations have been observed, as well as a number of recent talus cones along the steep mountain front (Maroukian et al. 1999). 


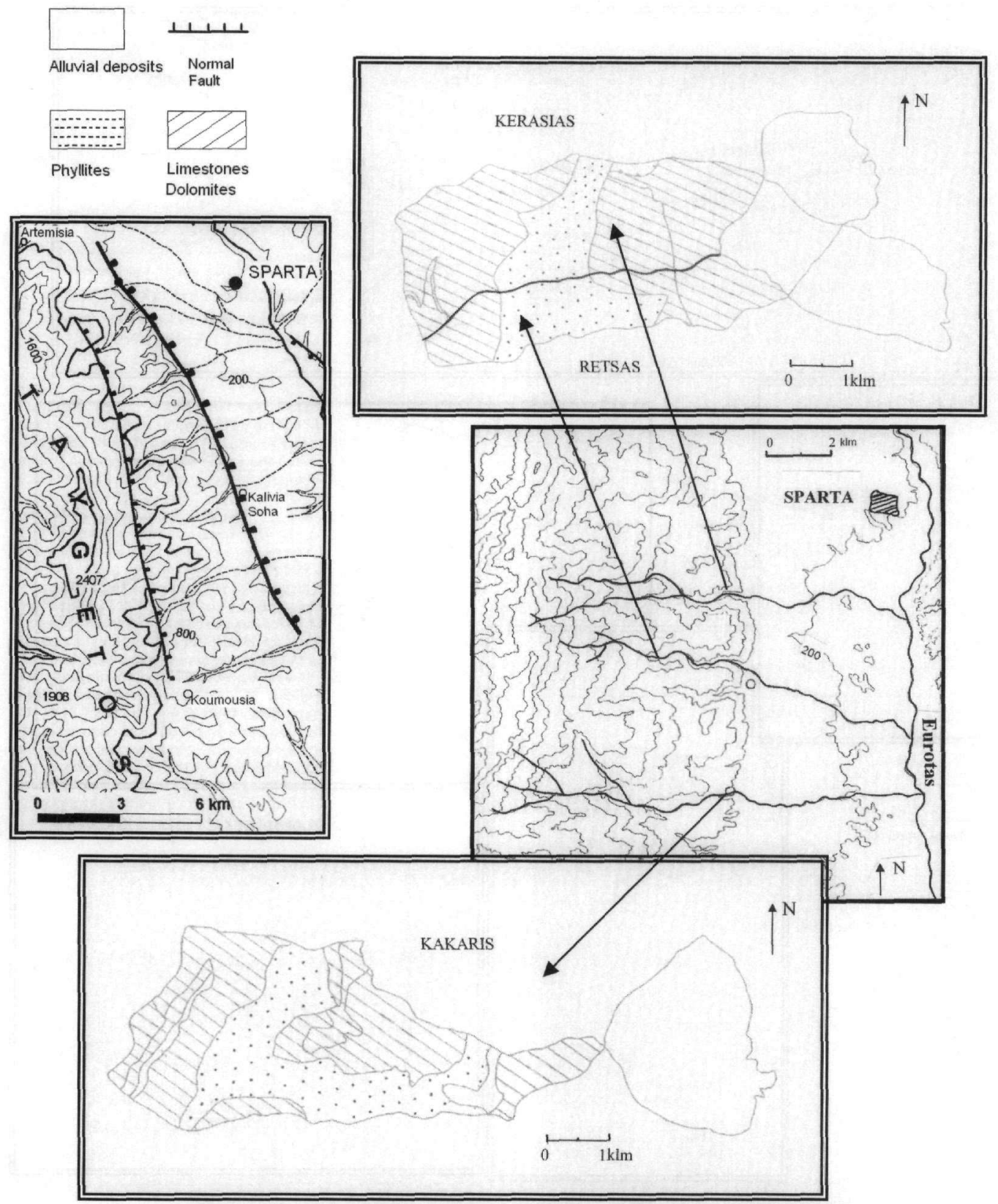

Figure 3 - Schematic geological maps of Eurotas tributaries

\subsection{Climate}

In the studied regions the Mediterranean climate type is prevalent. The analysis of ten meteorological station data (Lamia, Lefkada, Myriki, Neohori, Tymfristos, Vardates in Sperchios region and Artemisia, Kalivia Soha, Kastorio, Koumousia in Eurotas region), shows that lower temperatures and higher precipitation is observed in higher altitudes. The most humid months for Sperchios region are January, February, October and December $(85-320 \mathrm{~mm})$, while the drier ones are July and August. In the region of Eurotas, the most humid months are January and December $(75-320 \mathrm{~mm})$, while the drier one is July. In this region it is also observed that the mean monthly 
precipitation does not always follow a normal distribution, but frequently they present the highest in March and no rainfall in July or August. The annual range of temperature in both regions presents a simple fluctuation with maximums during July and minimums during January (Table 1).

Table 1 - Annual precipitation and temperatures in the studied areas

\begin{tabular}{|c|c|c|c|c|c|c|c|c|c|c|c|c|c|}
\hline & Jan & Feb & Mar & Apr & May & Jun & Jul & Aug & Sep & Oct & Nov & Dec & $\begin{array}{l}\text { Mean } \\
\text { Annual }\end{array}$ \\
\hline & \multicolumn{13}{|c|}{ Precipitation in Sperchios region } \\
\hline $\begin{array}{l}\text { Lamia } \\
(144 \mathrm{~m})\end{array}$ & 76,5 & 70,9 & 64,9 & 43,9 & 46,6 & 33,0 & 21,5 & 15,1 & 40,4 & 73,8 & 65,5 & 97,4 & 649,5 \\
\hline $\begin{array}{l}\text { Lefkada } \\
(390 \mathrm{~m})\end{array}$ & 116,5 & 140,2 & 93,5 & 67,8 & 50,1 & 30,0 & 15,7 & 20,3 & 37,4 & 124,1 & 115,7 & 120,0 & 931,3 \\
\hline $\begin{array}{l}\text { Neohori } \\
(800 \mathrm{~m})\end{array}$ & 252,2 & 226,4 & 196,9 & 163,9 & 123,9 & 63,2 & 38,1 & 28,1 & 72,4 & 190,0 & 227,6 & 323,1 & 1905,8 \\
\hline Snow $\%$ & 26 & 24 & 10 & - & - & - & - & - & - & - & - & 6 & \\
\hline $\begin{array}{l}\text { Tymfristos } \\
(720 \mathrm{~m})\end{array}$ & 170,5 & 147,6 & 126,5 & 94,1 & 59,2 & 35,6 & 17,3 & 20,0 & 47,3 & 127,7 & 160,5 & 193,0 & 1199,3 \\
\hline Snow $\%$ & 32 & 33 & 23 & - & $-\quad \mid$ & - & \begin{tabular}{l|l}
- & \\
\end{tabular} & $-\quad$ & - & - & 6 & 16 & \\
\hline \begin{tabular}{|l|} 
Vardates \\
$(25 \mathrm{~m})$
\end{tabular} & 71,8 & 81,0 & 59,0 & 50,2 & 30,7 & 12,9 & 19,7 & 20,1 & 19,9 & 84,6 & 58,3 & 71,1 & 579,3 \\
\hline & \multicolumn{13}{|c|}{ Temperatures in Sperchios region } \\
\hline $\begin{array}{l}\text { Lamia } \\
(144 \mathrm{~m})\end{array}$ & 7,4 & 8,8 & 11,3 & 15,5 & 20,4 & 25,2 & 27,6 & 27,1 & 22,9 & 17,9 & 13,4 & 9,3 & \\
\hline $\begin{array}{l}\text { Lefkada } \\
(390 \mathrm{~m})\end{array}$ & 5,3 & 7,2 & 10,0 & 13,2 & 18,8 & 23,5 & 25,8 & 24,2 & 20,7 & 15,4 & 10,9 & 7,7 & \\
\hline $\begin{array}{l}\text { Myriki } \\
(1100 \mathrm{~m})\end{array}$ & 3,0 & 3,8 & 6,8 & 10,0 & 15,7 & 19,6 & 21,8 & 21,3 & 18,5 & 13,3 & 8,1 & 5,0 & \\
\hline $\begin{array}{l}\text { Vardates } \\
(25 \mathrm{~m})\end{array}$ & 6,6 & 8,2 & 10,9 & 14,8 & 19,7 & 24,9 & 26,7 & 25,7 & 22,4 & 16,8 & 12,2 & 8,6 & \\
\hline & \multicolumn{13}{|c|}{ Precipitation in Eurotas region } \\
\hline $\begin{array}{l}\text { Artemisia } \\
(1100 \mathrm{~m})\end{array}$ & 167,8 & 145,6 & 96,7 & 72,4 & 40,9 & 17,5 & 15,3 & 16,8 & 43,4 & 94,1 & 168,8 & 212,5 & 1091,8 \\
\hline $\begin{array}{l}\text { KaliviaSoha } \\
(550 \mathrm{~m})\end{array}$ & 288,2 & 209,7 & 200,5 & 78,7 & 58,6 & 31,9 & 14,9 & 6,4 & 29,2 & 82,5 & 178,9 & 319,7 & 1499,1 \\
\hline $\begin{array}{l}\text { Kastorio } \\
(500 \mathrm{~m})\end{array}$ & 212,1 & 161,5 & 121,9 & 101,4 & 52,0 & 26,9 & 30,3 & 33,3 & 46,5 & 116,0 & 185,1 & 215,8 & 1302,8 \\
\hline $\begin{array}{l}\text { Koumousia } \\
(350 \mathrm{~m})\end{array}$ & 201,7 & 168,1 & 120,5 & 78,2 & 35,1 & 43,3 & 19,4 & 14,3 & 36,4 & 83,6 & 145,5 & 270,2 & 1216,3 \\
\hline & \multicolumn{13}{|c|}{ Temperatures in Eurotas region } \\
\hline $\begin{array}{l}\text { Artemisia } \\
(1100 \mathrm{~m})\end{array}$ & 5.7 & 6.6 & 8.4 & 12.2 & 17.7 & 21.9 & 24.4 & 24.0 & 20.5 & 15.8 & 11.5 & 7.8 & \\
\hline
\end{tabular}

\section{Methods}

\subsection{Morphometric characteristics}

Initially, mapping of drainage networks was made, as well as of drainage basins of the tributaries and the fans at a scale of 1:50.000 (Fig. 1). Measurements were made of the area of drainage basins (Ad), the fan area (Af), the slope of their main channel (Sc) and the slope of the fan (Sf). The relations Ad/Af and Sc/Sf were also calculated, as well as the altitudes of the fan apex (Hf), the relief between the fan apex and the fan apron (Da-ap) and the relief of the watershed height from the fan apex (Dw-a) (Table 2). The scatter of Ad/Af and Sc/Sf is shown in figures 4 and 5 respectively.

The construction of longitudinal stream profiles of the main channels of all the examined networks (Fig. 6), showed the various knick-points and slope changes that exist till the apron of the fan. In figure 6 , the faults that affect the slopes are marked with a continuous line, the lithological changes with an interrupted line and the apex of the fan with a cross. All the above with field work resulted in the following observations: 
Table 2 - Morphometric characteristics

\begin{tabular}{|c|c|c|c|c|c|c|c|c|c|}
\hline & $\begin{array}{c}\text { Ad } \\
\left(\mathbf{k m}^{2}\right)\end{array}$ & $\begin{array}{c}\text { Af } \\
\left(\mathbf{k m}^{\mathbf{2}}\right)\end{array}$ & $\mathbf{A d} / \mathbf{A f}$ & $\begin{array}{c}\text { Sc } \\
(\mathbf{\%})\end{array}$ & $\begin{array}{c}\text { Sf } \\
(\mathbf{\%})\end{array}$ & $\mathbf{S c / S f}$ & $\begin{array}{c}\text { Hf } \\
(\mathbf{m})\end{array}$ & $\begin{array}{c}\text { Da-ap } \\
(\mathbf{m})\end{array}$ & $\begin{array}{c}\text { Dw-a } \\
(\mathbf{m})\end{array}$ \\
\hline Tserlias & 5,125 & 5,060 & 1,01 & 22 & 9 & 2,4 & 400 & 240 & 1060 \\
\hline Xerias & 25,750 & 7,375 & 3,49 & 16 & 6 & 2,7 & 360 & 220 & 1690 \\
\hline Gorg/mos & 48,250 & 3,187 & 15,14 & 11 & 2 & 5,5 & 60 & 40 & 2090 \\
\hline Kerasias & 12,310 & 3,060 & 4,02 & 22 & 5 & 4,4 & 300 & 100 & 1720 \\
\hline Retsas & 7,187 & 4,000 & 1,80 & 22 & 3,5 & 6,3 & 300 & 100 & 1740 \\
\hline Kakaris & 15,060 & 5,750 & 2,62 & 21 & 3,8 & 5,5 & 320 & 100 & 2080 \\
\hline
\end{tabular}

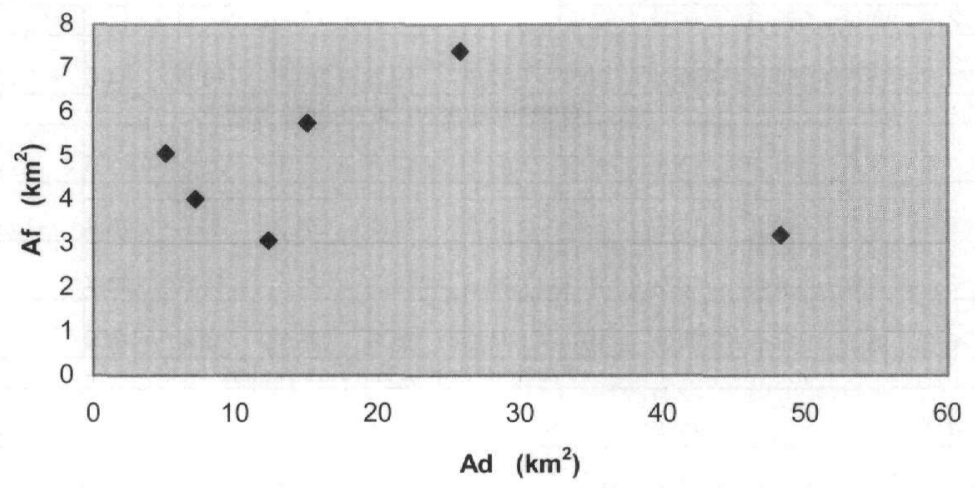

Figure 4 - Scattergram of Ad/Af

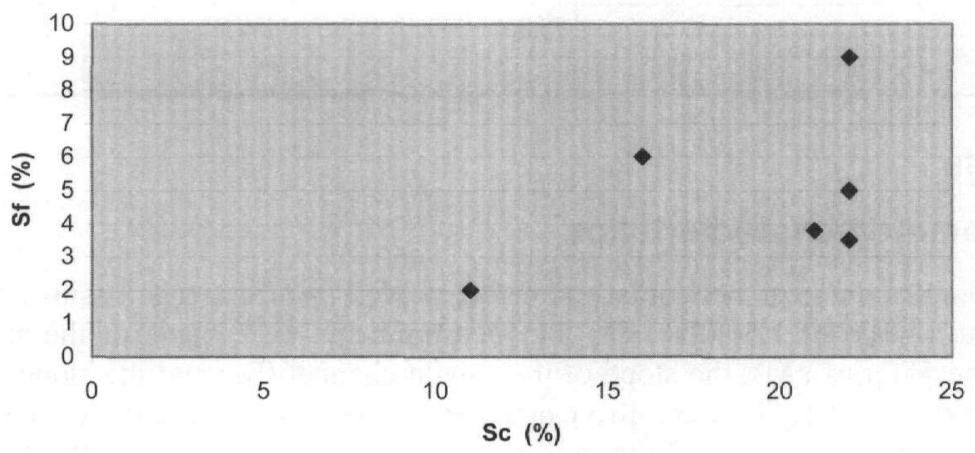

Figure 5 - Scattergram of Sc/Sf

Tserlias. The shape of the basin is oblong and its area is roughly equal to that of the fan. The stream flow has an orientation from south to north with few tributaries. Although there are no high altitudes (maximum elevation of watershed is $1467 \mathrm{~m}$. - apex of the fan at $400 \mathrm{~m}$ ) the relief is relatively steep. This is mainly due to the youthful stage of the stream ( $3^{\text {rd }}$ order streams only). The slope forms are quite smooth owed to the lithology of the basin, which is composed mainly of easily erodible flysch. All the above in combination with the steep slope of the stream (the highest among the three tributaries of Sperchios) have as a consequence the transport and accumulation of large amount of sediments and the creation of a large fan. (Photo 1). 


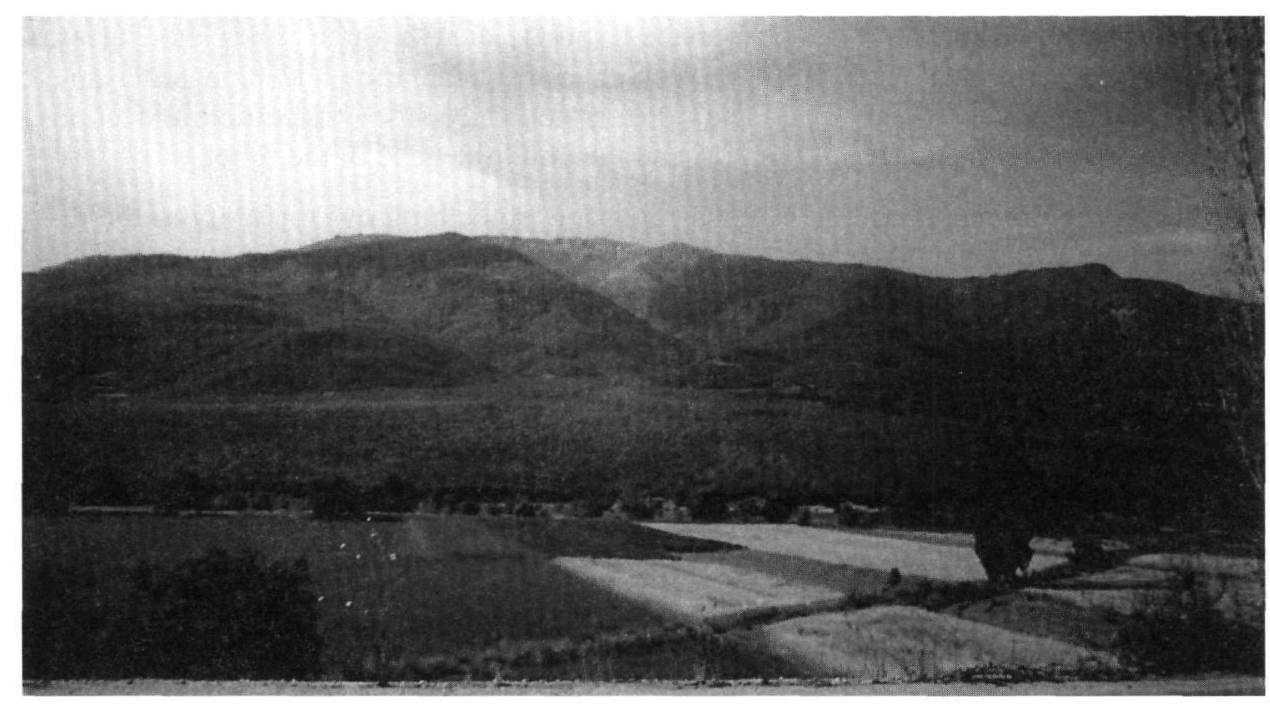

Photo 1 - Fan of Tserlias stream (from North to South)
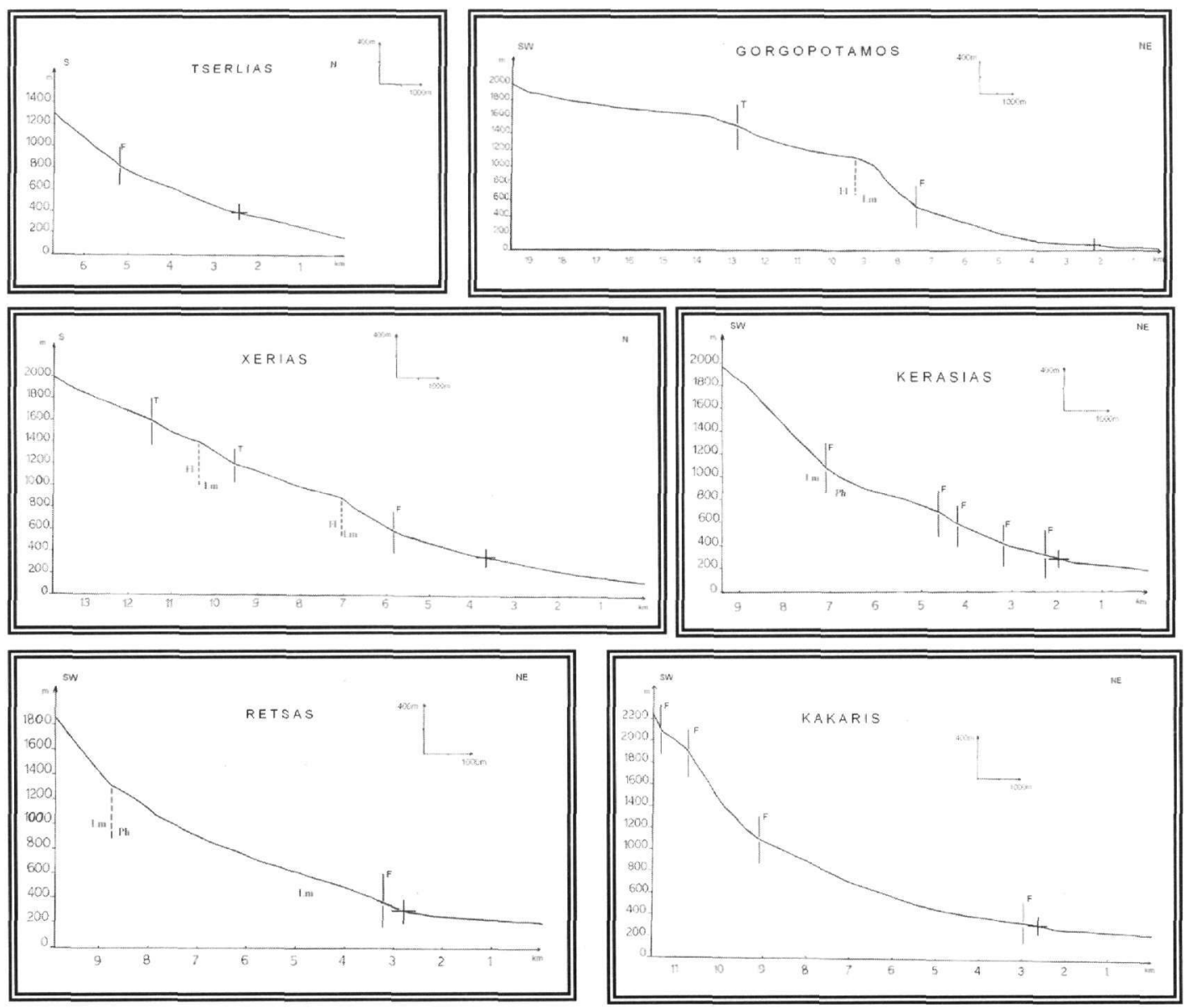

Figure 6 - Longitudinal stream profiles 
Xerias. Its drainage basin is almost pear-shaped and its area is three times the fan area. The orientation of the main channel is SSE-NNW with many tributaries and high order streams of small length and relatively steep slope. The relief is generally steep (maximum elevetions reach $2000 \mathrm{~m}$ ), that is owed to the uplift of mount Iti and the youthful stage of the relief.

Gorgopotamos. Its drainage basin is irregular in shape, something owed mainly to the dissimilar orientation of the two main tributaries (W-E for Valorrema and S-N for Ag. Pnevmatos). The extent of its drainage basin is much bigger than the fan's, compared to the other streams. The relief is generally smooth in the upper part of the network corresponding to a paleo-surface, while in the lower part intense erosion is observed corresponding to a rejuvenated region with a particularly characteristic deep gorge. The highest elevation is $2.200 \mathrm{~m}$ (Mount Iti) and the slopes are relatively steep, mainly because of the recent tectonism and the hard to erode limestones.

Kerasias. Its drainage basin is oblong and four times larger than the fan's. The stream flows from WSW to ENE and has two main tributaries. The highest altitude is $2024 \mathrm{~m}$ while the apex is at 300 $\mathrm{m}$, with steep relief. The high slopes favour the transportation of material although the prevailing lithology (marbles) is not favourable.

Retsas. Its drainage basin is particularly oblong with an area almost twice that of the fan's. The stream has a WSW to ENE direction with no significant tributaries but many first order streams. The highest altitude is $2045 \mathrm{~m}$, with steep relief and intense downcutting. All the above favour the transportation of a lot of material to the lower parts of the network.

Kakaris. It has a larger drainage basin than those of Kerasias and Retsas, with a remarkable elongation and almost triple area than the fan's. It flows from WSW to ENE and has several tributaries. The altitudes are higher than those of Kerasias and Retsas streams (up to $2.404 \mathrm{~m}$ ) and the relief is particularly steep with rocky slopes resulting to high transportation of weathered and eroded material.

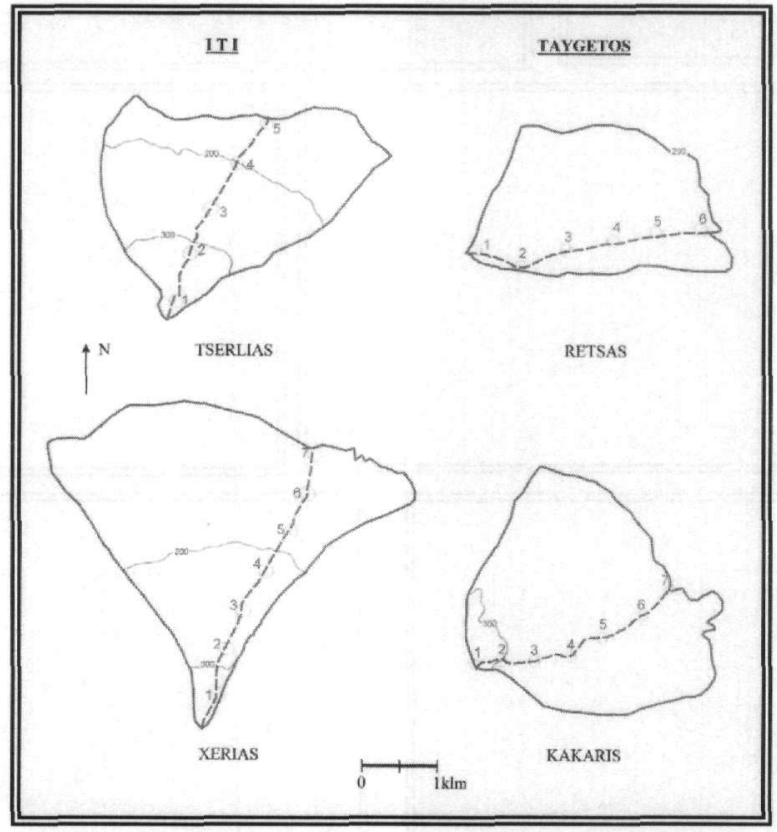

Figure 7 - Schematic diagram of pebble measurement locations

\subsection{Pebble measurements on fans}

During field work, pebble measurements were done, on the fans of Tserlias and Xerias tributaries of Sperchios river and on the fans of Retsas and Kakaris tributaries of Eurotas river. Pebble 
measurements were accomplished along the main (active) channel of the fans, at intervals of $500 \mathrm{~m}$, measuring the three axes $(\mathrm{a}, \mathrm{b}, \mathrm{c})$ of the 30 largest pebbles and then the flatness index $\mathrm{F}$ $(\mathrm{F}=\mathrm{a}+\mathrm{b} / 2 \mathrm{c})$ and the mean size $\mathrm{M}(\mathrm{M}=\mathrm{a}+\mathrm{b}+\mathrm{c} / 3)$ were calculated. The measurement locations are shown in the schematic diagram of figure 7 . Further to a quantitative analysis, general geomorphological observations were also made both on the channels and the surfaces of the fans (the lithological composition of pebbles, an approximate determination of percentages of sand, pebbles, blocks of rock, etc). Figures 8 and 9 show the flatness index $\mathrm{F}$ and the mean size $\mathrm{M}$ respectively.

$\square T S E R L I A S \square X E R I A S ~ \square R E T S A S ~ D K A K A R I S$

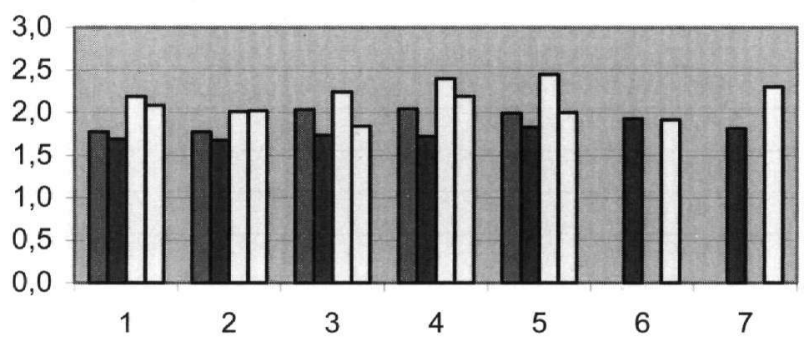

Figure 8 - Diagram of average flatness index (F)

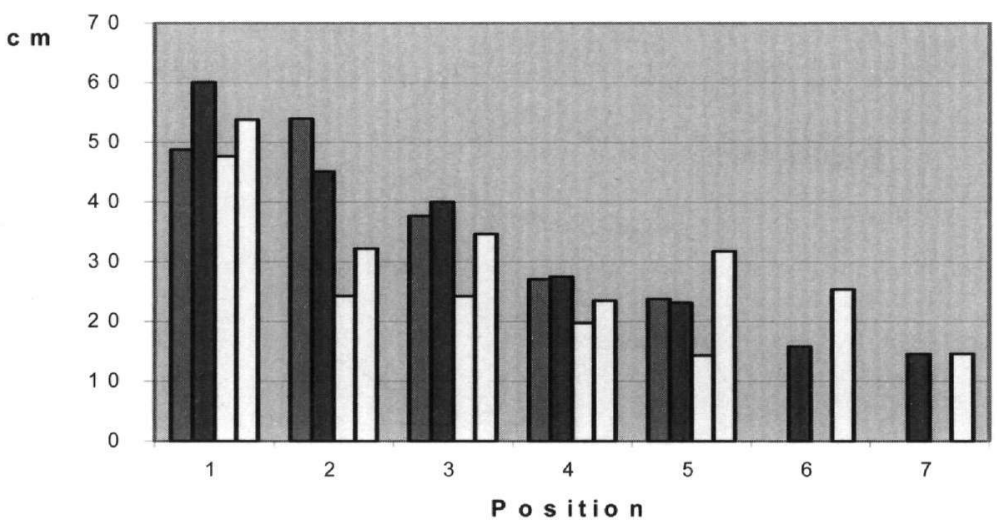

Figure 9 - Diagram of average mean size (M)

\subsection{Crenulations}

In order to realise the degree of erosion of the fans's surface and the implications that this has on the configuration of the relief and the braiding of stream channels, an examination of the crenulations was performed at $20 \mathrm{~m}$ contour intervals. The density of crenulation per unit length indicates the degree of erosion and indirectly the age of the fan surface, that is the older the deposition the more susceptible to the erosional processes.

This method was realised at a scale of 1:5.000 where the crenulations are clear as they do not appear in smaller scales. Then, the ideal smooth contour lines were imprinted, corresponding to an initial deposition stage (not eroded fan surface). The measurement of the length for both cases leads to the calculation of a crenulations index, that results from the relation of the length of the ideal contour lines to the length of the real contour lines. The closer to the unit it gets the lesser the erosion is. The individual indices for all the streams are shown in table 3. The imprinting of contour lines (real and ideal) in the upper part of Tserlias' fan (Photo 1) are indicatively shown in figure 10 . 
Table 3 - Erosion indices

\begin{tabular}{|c|c|c|c|c|c|c|}
\hline $\begin{array}{c}\text { Contour } \\
\text { lines }\end{array}$ & Tserlias & Xerias & Gorg/mos & Kerasias & Retsas & Kakaris \\
\hline 380 & 0,65 & & & & & \\
\hline 360 & 0,72 & & & & & \\
\hline 340 & 0,87 & 0,82 & & & & \\
\hline 320 & 0,89 & 0,80 & & & & \\
\hline 300 & 0,90 & 0,79 & & & & 0,67 \\
\hline 280 & 0,82 & 0,70 & & 0,83 & 0,66 & 0,78 \\
\hline 260 & 0,81 & 0,89 & & 0,73 & 0,81 & 0,85 \\
\hline 240 & 0,92 & 0,82 & & 0,77 & 0,77 & 0,86 \\
\hline 220 & 0,93 & 0,85 & & 0,89 & 0,85 & 0,79 \\
\hline 200 & 0,93 & 0,87 & & 0,89 & 0,91 & \\
\hline 180 & 0,95 & 0,92 & & & & \\
\hline 160 & 0,99 & 0,94 & & & & \\
\hline 140 & 0,93 & 0,79 & & & & \\
\hline 40 & & & 0,62 & & & \\
\hline 20 & & & 0,82 & & & \\
\hline
\end{tabular}

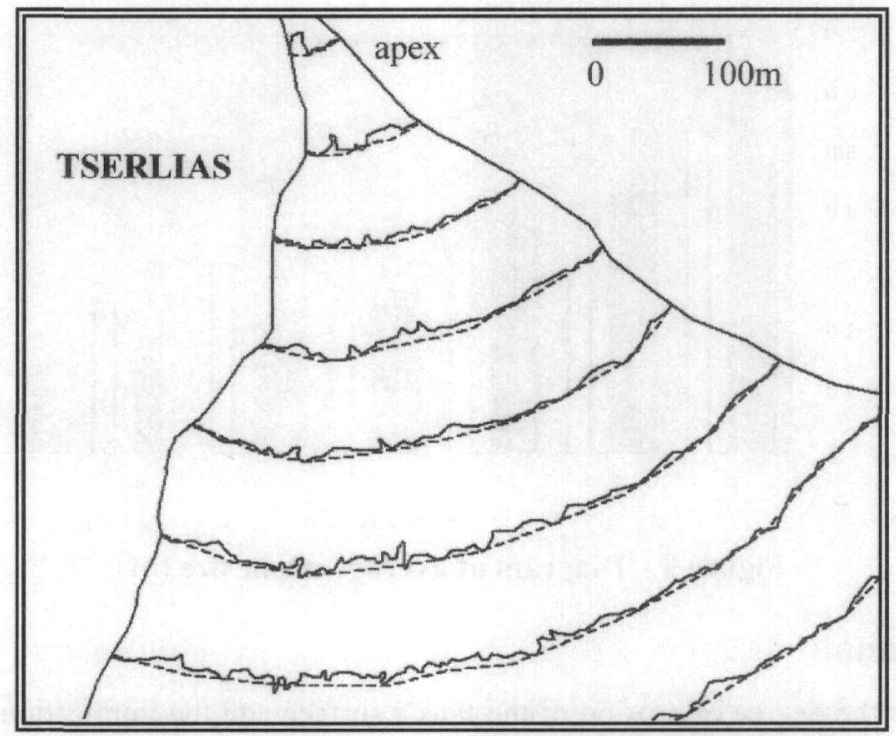

Figure 10 - Crenulations in the upper part of Tserlias' fan

\section{Results}

In general, the streans in the Sperchios region are active and present diverse watercourses on the fans. They mainly flow on easily erodible flysch, having as a result a smoother relief. On the contrary the relief is steep with hard to erode rocks or where recent tectonism influences the drainage network, forming a characteristic dendritic shape. The streams in Eurotas region present several morphological characteristics in common. All three fan apexes are found at the same altitude $(300 \mathrm{~m})$ and exhibit similar fan shapes and extent. The abrupt passage from the basin into the fan via a characteristically steep mountainous massif is owed to the Sparta fault, which actually delimits the fan apex (Photo 2). The main channel of the streams has created gorges because of the continuous uplift of Mount Taygetos. 


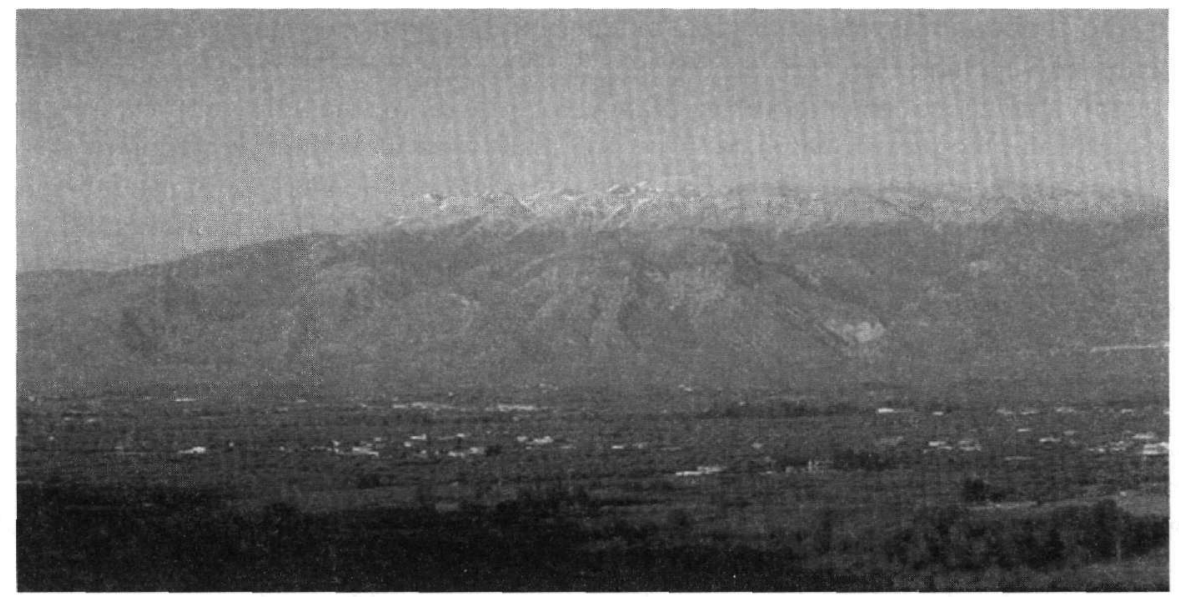

Photo 2 - Eastern front of Mount Taygetos with alluvial fans in the foreground

From the gravelometry, it was found that the flatness index F exhibits no discernible difference, which means that there is actually no pattern, that is probably due to the small size of the fans. It is also obvious that the mean size $M$ presents an expected gradational decrease in size the closer we get to the apron of the fan. All the other measured morphometric characteristics compare well with the ones of previous studies (Hooke 1965, Maroukian 1975, Harvey 1997).

From field observations it is obvious that the fans in the Sperchios region present a higher percentage of finer material in the lower parts of the fan, mainly of argilic composition. On the contrary, at the apex of the fans several blocks of limestone rocks exist. They exhibit braided channels and the vegetation is particularly developed, especially on Tserlia's fan. The fans of Eurotas region present a greater percentage of silt in their watercourses while the limestone pebbles are fewer. Their channels are not braided and the vegetation is quite dense.

Following the crenulations data of table 3, it is obvious that Tserlias' fan presents the smaller erosion and the smoothest surface (Photo 1). On the contrary, the fans of the streams of Eurotas region have undergone greater erosion than those of Sperchios region. In the case of Gorgopotamos, its alluvial fan is rather small and exhibits low slope, which gives only two erosion indices.

\section{Discussion - Conclusions}

With the present study an effort was made to record and correlate the data from two groups of alluvial fans (Sperchios and Eurotas regions), so that the factors that mainly influence the shaping and development of fans in these two parts of Greece can be determined. Firstly, the fault tectonism controls to a great extent the evolution of the networks of both regions. In the region of Sperchios the asymmetrical tectonic graben influences the appearance of the fans in the southern part of the basin, which uplifts. On the other hand, the placement of the apexes of the fans at the same altitude in the region of Eurotas is very characteristic, owed to the big active fault of Sparta which runs through eastern Taygetos.

Lithology is the second factor that determines both the shape of valleys in the hydrologic basin and the shape of the fans as well as the volume of material provided by the rivers at the exit from the mountainous massif. Thus, observing the basins in the region of Sperchios we see that they are mainly composed of flysch and other easily erodible rocks, which provide large quantities of material transported from the active rivers and resulting in fans of great extent. On the contrary, the region of Eurotas consists of hard to erode rocks, so that there is small supply of material in the fans of the streams Kerasias, Retsas and Kakaris, having as a result a limited area. 
Moreover, the climate influences to a great extent both the supply of material from the rivers and the existence of vegetation on the fans. While both regions have almost the same climate and accept roughly the same quantity of rainfall, the growth of the alluvial fans is particularly characteristic in the region of Sperchios. This is probably owed to the orientation of the drainage basins (they have a general S-N orientation), that contributes to the increase of rainfall and snow in them. On the other hand, the basins in the region of Eurotas have a W-E orientation, where the mountainous massif of Taygetos creates a "shade" in the humid air masses that are moving from west to east.

Comparing the rivers in the two regions it becomes obvious that they differ considerably in the shape and the size of their drainage basins, the relief and the type of rocks that they cross, the configuration of their channels into the fan, the type of their drainage networks, the stage of development, as well as the degree of processes they undergo. This differentiation is mainly owed to the above mentioned factors and the fact that they are two different regions with different evolution through time. The region of Sperchios is a rejuvenated area, with the characteristic small drainage basin of Tserlias which is truncated in the south by a large tributary of Sperchios river. The region of Eurotas is characterized by the continuous uplift of the mountainous massif of Taygetos. Almost all the streams present knick-points owed mainly to recent tectonism and lithological differentiations. Moreover, the fans of the streams of Eurotas region have undergone greater erosion than those of Sperchios region.

The rivers of Eurotas region are all in a youthful stage with a simple drainage network and oblong basin. They all flow on a relatively steep relief composed by rocks of the same unit and thus giving fans of similar shape with a non-braided channel. Moreover, all morphometric characteristics do not exhibit large fluctuations, resulting in the same shape and slope.

On the contrary, the rivers of Sperchios region do not all present the same fan characteristics and their drainage basins have also different shape and extent. Xerias and Tserlias are in a youthful stage, while Gorgopotamos is in a stage of maturity with the exception of its lower rejuvenated part. A common characteristic is the dendritic type of their drainage network and their braided channel onto the fan. The area of the drainage basins is generally bigger than those of the basins in Eurotas region. The same goes for the fan area too, as well as for the relation Ad/Af. These parameters exhibit significant fluctuations resulting in fans of both large and small extent. Tserlias is a characteristic case, presenting a basin and a fan of the same extent with a steep slope, due to a very active river being in a youthful stage of development.

In conclusion, the recent tectonism, the prevailing lithology and the climate are the main factors which influence the shape, the area and all the distinct characteristics of the fans and determine their development through time.

Two anonymous reviewers are acknowledged for their useful comments on the manuscript.

\section{References}

Anstrey R.L., 1965. Physical characteristics of alluvial fans. U.S. Army Natick Laboratories, Technical Report ES-20.

Armijo, R., Lyon-Caen, H.. and Papanastasiou, D., 1991. A possible normal-fault rupture for the 464 BC Sparta earthquake, Letters to nature, 351.

Bull W.B., 1977. The alluvial fan environment, Progress in physical Geography, 1, 222-270.

Gaki-Papanastasiou, K., Papanastasiou, D., and Maroukian, H., 1995. Geomorphological and seismotectonic observations in the area of Sparta. Proc. $4^{\text {th }}$ Panhellenic Geogr. Conf., 1998.

Eliet, P.P,. and Gawthorpe, 1995. Drainage development and sediment supply within rifts, examples from the Sperchios basin, central Greece, Journal of the Geological Society, London, 152, 883-893. 
Harvey, A., 1997. The role of alluvial fans in arid zone fluvial systems, John Wiley \& Sons Ltd, New York, U.S.A.

Harvey, A., 2002. The role of base-level change in the dissection of alluvial fans: case studies from southeast Spain and Nevada, Geomorpholog,y 45, 67-87.

Hooke, R.L., 1965. Alluvial fans. Ph. D. Dissertation, Institute of Technology, California. University Microfilms, Michigan, U.S.A.

Lecce, S.A., 1988: The alluvial fan problem, Arisona State University, Tempe, Arisona, U.S.A.

Mariolakos, I., 1976. Thoughts and view points problems of the geology and tectonics of Peloponnesus (Greece), Ann Geol. Pays Hellen., 27, 215-313.

Maroukian, H.S., 1975. A morphometric analysis of selected alluvial fans in the basin and range province, Master's thesis, Louisiana State University, U.S.A. (unpublished)

Maroukian, H.S., 1987: Physico-geographic observations in the drainage basin of Sperchios river, Ph. D. Dissertation, University of Athens. (In Greek).

Maroukian, H., Papanastasiou, D., and Gaki-Papanastasiou, K., 1999. Paleogeographic evolution and seismotectonic implications of the broader area of Eurotas river (Greece) during the Quaternary, Z. Geomorph. N.E., 118, 135-146.

Moore, T.E., and Nilsen, T.H., 1984. Bibliography of Alluvial fan deposits, Geo Books, Norwich, England.

Papanikolaou, D., 1986. Geology of Greece, Athens, 240p. (in Greek).

Papanastasiou, D., Gaki-Papanastasiou, K., Maroukian, H., Karympalis, E., and Makaris, D., 2000. Implications of morphology and seismicity on the hazard assessment in the monuments of Mystras in Southern Peloponnesus, Greece, Ann Geol. Pays Hellen., 38, 157-173.

Papanastasiou, D., Gaki-Papanastasiou, K., and Maroukian, H., 2005. Recognition of past earthquakes along the Sparta fault (Peloponnesus, southern Greece) during the Holocene, by combining results of different dating techniques, Journal of Geodynamics, 40, 189-199.

Pope, R., and Millington, A., 2002. The role of alluvial fans in mountainous and lowland drainage systems: examples from the Sparta basin, Lakonia, southern Greece, Z. Geomorph. N.F. 46 (1), 109-136.

Pope, R., Wilkinson, K., and Millington, A., 2003. Human and Climatic Impact on Late Quaternary Deposition in the Sparta Basin Piedmont: Evidence from Alluvial Fan Systems, Geoarchaeology:An International Journal, 18, (7), 685-724.

Rachochi, A.H., 1981. Alluvial fans, John Wiley and sons, New York, U.S.A.

Volker, H.X., Wasklewicz, T.A., and Ellis, M.A., 2006. A topographic fingerprint to distinguish alluvial fan formative processes, Geomorphology, (in press) 